\title{
PENCIPTAAN BUSANA ANAK DENGAN MENERAPKAN TEKNIK SUBSTRACTION CUTTING
}

\author{
Esther Mayliana ${ }^{1}$ (Institut Seni Indonesia Yogyakarta)
}

\begin{abstract}
Children's clothing is clothing used by children in the age range of 6-12 years. Children's clothing has the main criteria that is comfortable when used. Comfort can be obtained from the choice of the type of material used and the design of children's clothing. The process of making fashion is very varied, and is increasingly developing, one of which is the Substraction cutting technique. Clothing made with substraction cutting techniques is usually women's clothing. This study wanted to examine the application of Substraction cutting techniques with the Tunnel method to make children's clothing. This study has 3 objectives, that is to find out how to make children's clothing with Substraction cutting techniques, efficient use of materials and speed of the fashion making process. This research uses the Action Reserch method. The method of creation through 3 stages, that is exploration, design and realization. In this study several techniques in pattern placement were carried out, and the results were: (1) Making clothes with the substraction cutting technique does not require two circle patterns to increase the volume, but just one circle pattern if needed., (2) Fabric folds when cutting material is necessary pay attention to produce the desired length of clothing, (3) The volume produced from the substraction cutting technique can be completed by draping technique, as decoration that is part of the children's clothing, (4) Substraction cutting technique removes relatively little fabric (5) The process that is passed is enough fast because it cuts down several stages in the process of making fashion in general.

Keywords: Children's Clothing, Substraction Cutting, Tunnel
\end{abstract}

\begin{abstract}
ABSTRAK
Busana anak adalah busana yang digunakan oleh anak di rentang usia 6-12 tahun. Busana anak memiliki kriteria utama yaitu nyaman saat digunakan. Kenyamanan dapat diperoleh dari pilihan jenis bahan yang digunakan serta desain busana anak. Proses pembuatan busana sangat bervariasi, dan semakin berkembang, salah satunya adalah teknik Substraction cutting. Busana yang dibuat dengan teknik Substraction cutting biasanya adalah busana wanita. Penelitian kali ini ingin meneliti penerapan teknik Substraction cutting dengan metode Tunnel untuk membuat busana anak. Penelitian ini memiliki 3 tujuan, yaitu untuk mengetahui bagaimana cara membuat busana anak dengan teknik Substraction cutting, efisiensi penggunaan bahan dan kecepatan proses pembuatan busana. Penelitian ini menggunakan metode Action Reserch. Metode penciptaan melalui 3 tahapan yaitu eksplorasi, perancangan dan perwujudan. Pada penelitian ini beberapa tehnik dalam penempatan pola dilakukan, dan hasilnya adalah: (1) Pembuatan busana dengan teknik Substraction cutting tidak diperlukan dua pola lingkaran untuk penambah volume, namun cukup satu pola lingkaran jika diperlukan., (2) Lipatan kain saat memotong bahan perlu diperhatikan untuk menghasilkan panjang busana yang diinginkan, (3) Volume yang dihasilkan dari teknik Substraction cutting dapat diselesaikan dengan teknik draping, sebagai hiasan yang menjadi bagian dari busana anak, (4)Teknik Substraction cutting membuang kain relatif sedikit (5) Proses yang dilalui cukup cepat karena memangkas beberapa tahap dalam proses pembuatan busana pada umumnya. Kata kunci: Busana Anak, Substraction Cutting, Tunnel
\end{abstract}




\section{PENDAHULUAN}

Busana merupakan salah satu hal yang penting kehidupan manusia. Manusia menggunakan busana sejak zaman purba. Proses pembuatan busana diawali dengan cara yang sederhana, yaitu mengolah bahan alam menjadi bahan yang digunakan untuk membuat busana. Proses pembuatannya juga mengunakan teknik yang sederhana, sehingga menghasilkan busana dengan bentuk yang sederhana, namun sesuai dengan kebutuhan pada masa itu.

Seiring berkembangnya zaman, busana memiliki perubahan dari sisi bahan yang digunakan hingga proses pembuatan. Perubahan tersebut di pengaruhi oleh banyak hal, diantaranya kebutuhan dan keinginan manusia, perkembangan teknologi, dan kreatifitas manusia. Salah satu perubahan yang terjadi adalah pada teknik pembuatan busana. Proses pembuatan busana pada umumnya dimulai dari menentukan desain, kemudian dilanjutkan dengan pembuatan pola dasar dan pecah pola sesuai desain. Dengan pola yang sudah dimiliki, cutting bahan dilakukan sesuai dengan pola. Proses selanjutnya adalah menjahit kain yang sudah dipotong menjadi busana yang sesuai dengan desain yang dibuat. Proses ini, memiliki prinsip pola dibuat berdasarkan desain.

Kreatifitas manusia memberikan ide tentang proses pembuatan busana secara berbeda. Saat ini muncul satu teknik baru, yaitu teknik substraction cutting yang merubah proses pembuatan busana. Teknik substraction cutting di ciptakan oleh Julian Roberts. Teknik substraction cutting merupakan teknik cutting yang pada pelaksanaannya menghilangkan sebagain kecil dari lembaran kain, sehingga tidak banyak kain yang terbuang. Kain tersebut di jahit sedemikian rupa sehingga menghasilkan busana yang memiliki nilai keunikkan yang muncul dari hasil potongan dan jahitan yang diaplikasikan. Prinsip dari teknik ini adalah merancang dengan pola dan bukan menciptakan desain dengan pola. Teknik ini banyak digunakan untuk membuat busana wanita dewasa, karena keunikkan yang dihasilkan dari teknik substraction cutting. Keunikan ini menjadi seni tersendiri dan nampak fashionable pada saat digunakan.

Busana dapat diklasifikasikan menjadi beberapa kelompok, salah satunya berdasarkan usia pemakainya, diantaranya; busana bayi , busana kanak-kanak, busana anak, busana remaja, busana dewasa, busana masa tua. Dalam masing- masing kelompok memiliki kriteria tertentu yang disesuaikan dengan kondisi masing-msaing usia pemakai. Terkait dengan penelitian yang akan dikerjakan yaitu busana anak, berdasarkan eksplorasi yang dilakukan oleh peneliti, teknik substraction cutting belum pernah dilakukan untuk membuat busana anak. Busana anak dibuat dengan proses pada umumnya, hal ini kurang memberikan inovasi pada pembuatan busana anak, baik dari desain, maupun proses pembuatan busana anak.

Proses dalam pembuatan busana, biasanya menghasilkan limbah tekstil. Limbah ini muncul dari sisa potongan yang tidak digunakan dalam proses pembuatan busana. Limbah tekstil dapat dikatakan sebagai pemasok limbah terbesar kedua di dunia. Kondisi ini tidak menutup kemungkinan dapat merusak lingkungan, karena belum dapat dimanfaatkan secara cepat dan maksimal. Keterbatasan tenaga manusia dalam memanfaat limbah tersebut memberikan dorongan untuk dapat mengembangkan tehnik pembuatan busana dengan mengurangi terciptanya limbah tekstil.

Zaman modern seperti saat ini, waktu merupakan hal yang sangat berharga, efektifitas dan efisiensi dalam melakukan berbagai macam kegiatan menjadi bagian yang penting untuk diupayakan. Hal ini juga 
dicoba untuk di terpkan pada kegiatan produksi busana. Kebutuhan manusia saat ini terhadap busana, menjadi alasan utama menuntut produsen dapat menghasilkan busana dengan waktu yang efektif dan efisien. Waktu produksi busana yang efektif diharapkan tidak mempengaruhi hasil dan kualitas dari busana yang dihasilkan. Dengan kreatifitas manusia berbagai sistem diciptakan dan dikembangkan untuk mencapai efektifitas dan efisiensi.

Berdasarkan latar belakang diatas, perumusan masalah pada penelitian ini adalah sebagai berikut:

1. Bagaimanakah cara menciptakan busana anak dengan teknik substraction cutting?

2. Bagaimana efisiensi penggunaan kain pada proses pembuatan busana anak dengan teknik substraction cutting?

3. Bagaimana kecepatan proses pembuatan busana anak dengan teknik substraction cutting dibandingkan dengan proses pembuatan busana anak dengan teknik konstruksi.

\section{Busana}

Kata busana diambil dari bahasa Sansekerta "bhusana" dalam bahasa jawa dikenal dengan " busono". Kata tersebut memiliki arti yaitu perhiasan, dan dalam bahas Indonesia terjadi pergesaran arti busana menjadi padanan "pakaian". Busana dapat dikeompokkan berdasarkan usia, dintaranya busana bayi, anak, remaja, dewasa dan masa tua. Masing masing kelompok memiliki rentang usia yang berbeda-beda. Busana anak masuk rentang usia 6-12 tahun, pada penelitian kali ini busana anak yang dibuat untuk usia 7-9 tahun. Busana anak memiliki prinsip kenyamanan baik dari segi bahan maupun desain busana tersebut. Berikut kriteria busana anak:

1. Busana cenderung longgar, sehingga memberikan kemudahan dalam bergerak
2. Mudah dalam mengenakan dan membuka baju

3. Jenis kain yang digunakan, menyerap keringat, kuat dan mudah dalam perawatannya,

4. Warna kain untuk busana anak yang dipilih adalah warna cerah

5. Motif yang dilipih, bermotif kecil

6. Bahan yang dipilih memiliki ketebalan sedang, jangan terlalu tipis atau tebal.

7. Jika menggunakan garnitur busana, dipilih yang sesuai baik ukuran, warna maupun bentuknya dan yang paling penting pemasangannya harus kuat/ tidak mudah lepas.

\section{Substraction Cutting}

Substraction Cutting dapat
dikatakan merupakan salah satu proses
pembuatan busana yang baru dan belum
banyak digunakan saat ini. Teknik
Substraction cutting menggunakan
metode pengurangan, jadi bentuk yang
dihasilkan dibuat dengan cara
menghilangkan kain, bukan menambah
kain. Penghilangan kain menciptakan ruang
bagi tubuh dan membentuk kain yang jatuh di
sekitar tubuh. Teknik ini memiliki prinsip
merancang pakaian dengan pola. Terdapat 3
metode yang digunakan dalam Teknik
Substraction cutting, yaitu Teknik Tunnel,
TeknikPlug dan Teknik Displacement.

\section{Teknik Tunnel}

Pada penelitian ini di terapkan teknik Tunnel untuk membuat busana anak. Teknik Tunnel biasanya digunakan untuk pembuatan busana wanita. Ukuran bahan yang digunakan minimal $150 \mathrm{~cm} \times 180 \mathrm{~cm}$. Jika memiliki kain yang lebih panjang juga dapat digunakan untuk membentuk volume. Kain bisa terdiri dari 1 jenis (warna, motif), atau dikombinasi 2 hingga 3 jenis kain. Pola yang digunakan berupa pola badan depan 
dan pola badan belakang dan pola lingkaran dengan jari-jari 1/6 lingkar panggul.

Proses awal penggunaan teknik ini, kain dibuat selonsong dan ditutup di salah satu sisinya. Pola badan depan dan belakang diletakkan berhadapan, sedangkan pola lingkaran di letakkan dibagian bawah pola badan dengan jumlah genap, karena lingkaran tersebut nantinya akan saling di satukan.

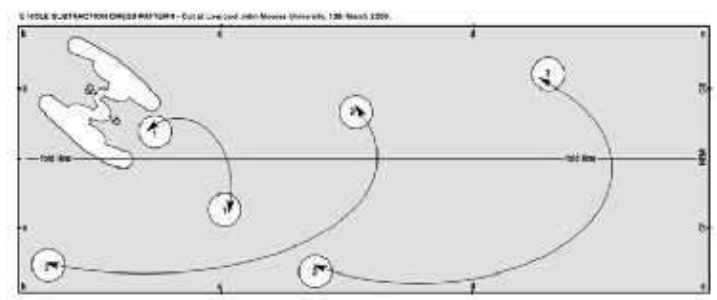

Gambar 1. Peletakkan pola pada teknik Tunnel Sumber:

https://amberdebbage.wordpress.com/2013/11/05/sub traction- cutting/ diakses tgl 31 Agustus 2018, pukul 10.00

Setelah meletakkan pola pada kain, kain dipotong sesuai dengan bentuk pola dan diberikan tanda rader. Proses menjahit diawali dengan menjahit bahu, sisi dan menyatukan lingkaran yang sudah dibuat. Penyelesaian kerung lengan, kerung leher dan rok bagian bawah dapat dilakukan menggunakan berbagai teknik jahit. Hasil akhir dari busana yang dibuat dengan teknik Tunnel secara umum memiliki panjang yang berbeda antara depan dan belakang, volume didapatkan karena sambungan selongsong, sambungan sisi dan pola lingkaran yang disatukan. Besar dan bentuk volume, tergantung dari peletakkan pola.

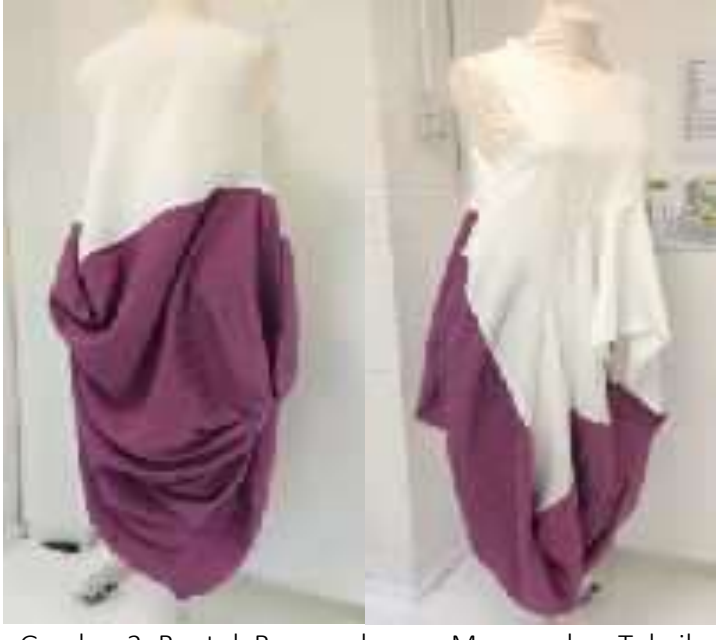

Gambar 2. Bentuk Busana dengan Menerapkan Teknik Tunnel

\section{PEMBAHASAN}

\section{Teknik Substraction cutting untuk membuat busana anak}

Untuk busana anak dengan beberapa percobaan menggunakan ukuran kain yang berbeda-beda, peletakkan pola serta jahitan Tunnel juga diterapkan secara berbeda. Penggunaan kain dapat divariasi dengan 2 jenis kain yang berbeda motif atau warna. Proses awal di buat terlebih dahulu pola dasar anak kemudian dirubah pada garis leher dan kerung lengan untuk di bentuk sesuai desain.

Pola dasar anak, untuk usia7-9 tahun, dengan ukuran badan:

Lingkar badan : $66 \mathrm{~cm}$

$\begin{array}{ll}\text { Panjang punggung } & : 29 \mathrm{~cm} \\ \text { Lebar punggung } & : 28 \mathrm{~cm} \\ \text { Panjang muka } & : 25 \mathrm{~cm} \\ \text { Lebar muka } & : 26 \mathrm{~cm} \\ \text { Lingkar leher } & : 29 \mathrm{~cm} \\ \text { Lingkar pinggang } & : 58 \mathrm{~cm} \\ \text { Lingkar panggul } & : 66 \mathrm{~cm} \\ \text { Tinggi panggul } & : 15 \mathrm{~cm} \\ \text { Panjang bahu } & : 10 \mathrm{~cm} \text { Lingk. } \\ \text { lubang lengan } & : 30 \mathrm{~cm}\end{array}$




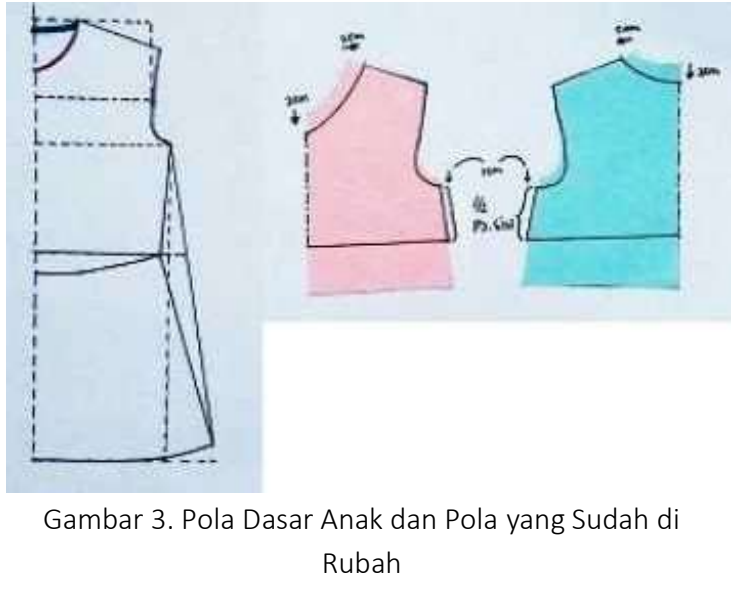

a. Desain 1

Ukuran kain : $75 \mathrm{~cm} \times 200 \mathrm{~cm}$

Lipatan: dibuat tidak seimbang pada bagian lipatan panjang. Peletakkan pola:

Tidak simetris

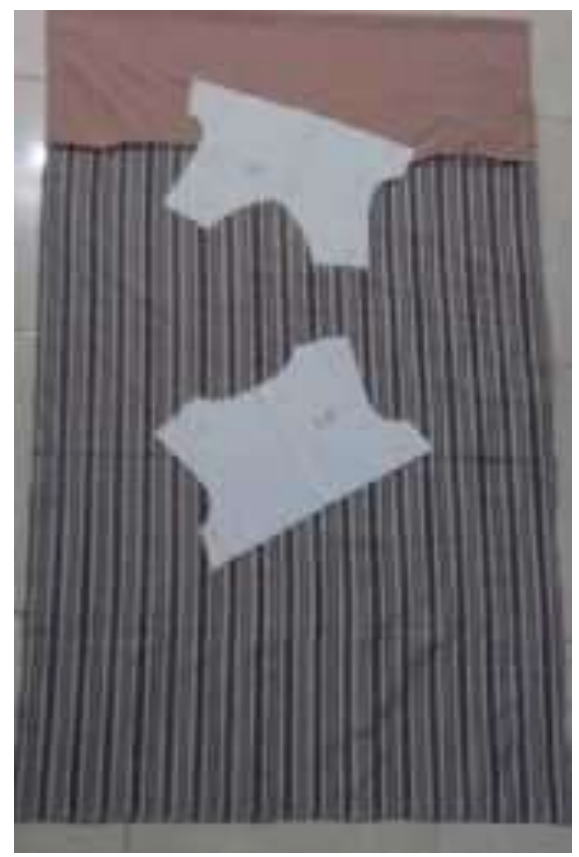

Gambar 4. Peletakkan pola

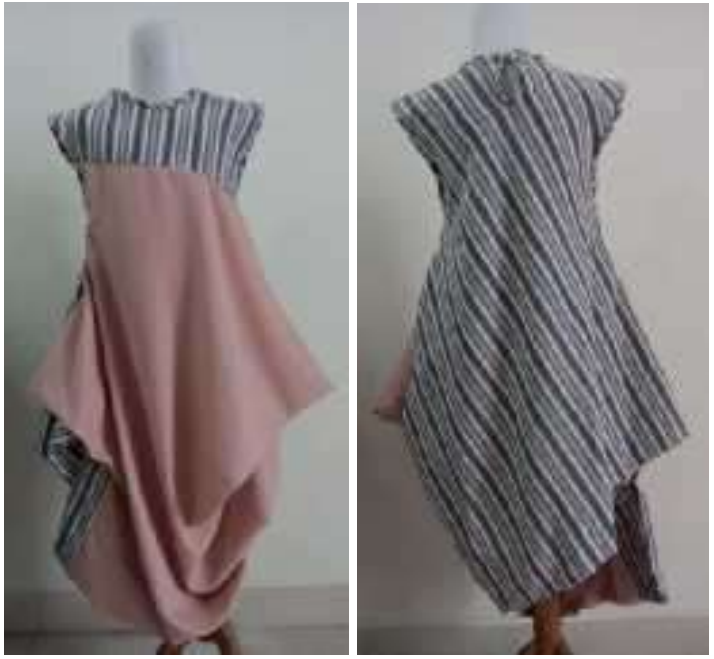

Gambar 5. Hasil busana

\section{Pembahasan Desain 1:}

Kain dengan panjang $200 \mathrm{~cm}$ dilipat dengan posisi panjang yang tidak sama, yaitu pada bagian depan memiliki panjang lebih $50 \mathrm{~cm}$ dari pada kain di posisi belakang. Pola diletakkan pada posisi tidak simetris, pola badan depan pada posisi dekat lipatan kain untuk menghasilkan volume pada bagian depan. Kerung lengan depan dan belakang masing-masing di sambungkan dengan bentuk yang tidak sama pada sisi kanan dan sisi kiri.

Hasil busana anak yang dihasilkan terdapat volume pada bagian sisi kanan dan kiri serta pada bagian depan. Pada bagian belakang tanpa volume dan bagian bawah berbentuk menyudut.

\section{b. Desain 2:}

Ukuran kain: 75 cm x $200 \mathrm{~cm}$ Lipatan: dibuat seimbang pada bagian panjang. 


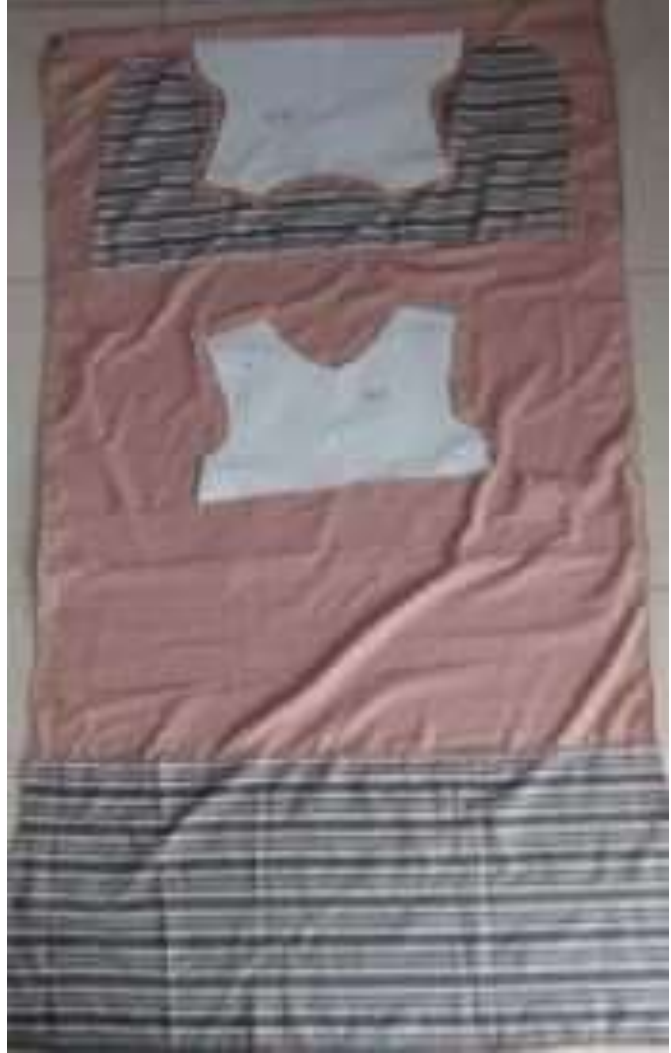

Gambar 6. Peletakkan pola Simetris

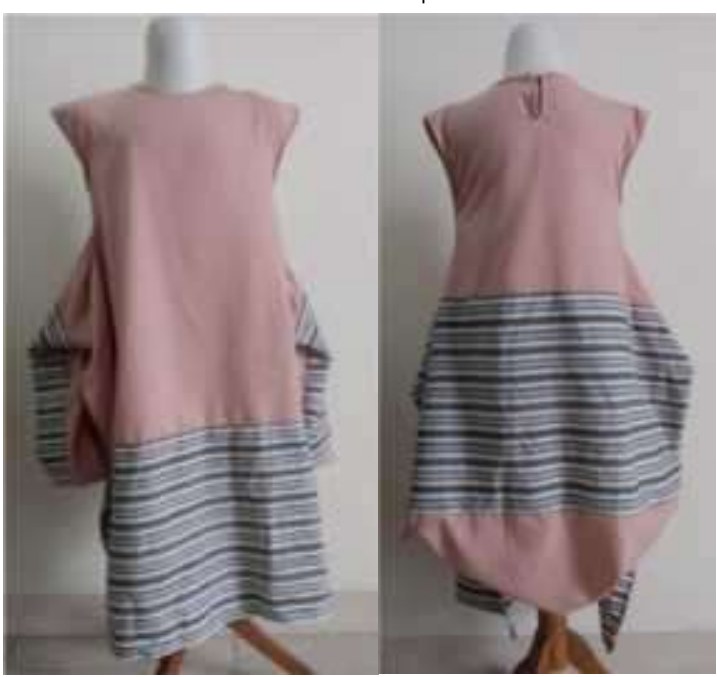

Gambar 6. Hasil busana

\section{Pembahasan Desain 2:}

Kain dengan panjang $200 \mathrm{~cm}$ dilipat dengan posisi panjang yang tidak sama, yaitu pada bagian depan memiliki panjnag lebih $50 \mathrm{~cm}$ dari pada kain di posisi belakang. Pola diletakkan pada posisi simetris simetris, Pola badan belakang pada posisi dekat lipatan kain untuk menghasilkan volume pada bagian belakang. Kerung lengan depan dan belakang masing-masing di sambungkan dengan bentuk yang simetris pada sisi kanan dan sisi kiri.

Hasil yang didapatkan adalah baju memiliki volume yang simetris, Volume nampak pada bagian belakang, dan kerung lengan pada sisi kanan dan sisi kiri. Pada bagian depan tanpa volume dan lurus simetris. Sentuhan draping perlu dilakukan pada hasil busana ini sehingga menghasilkan busana anak yang menarik.
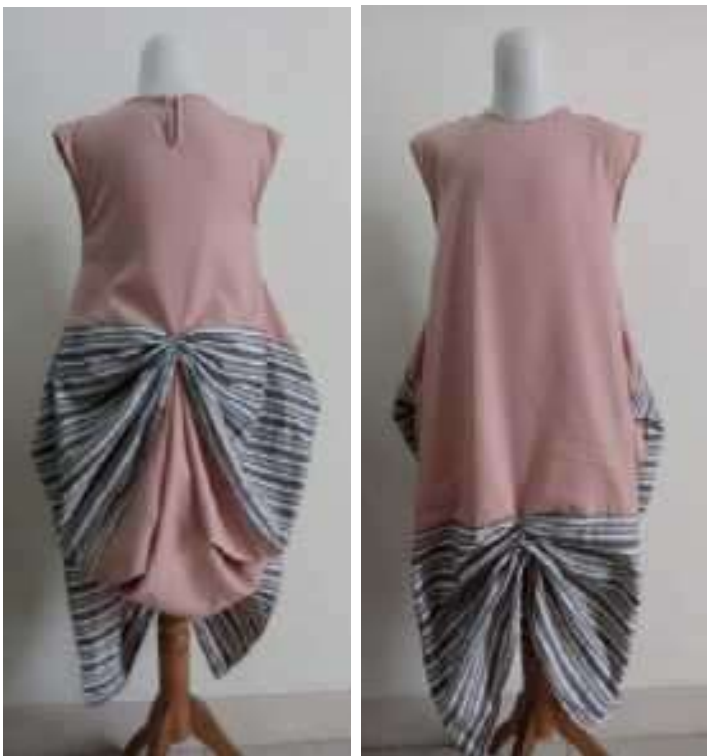

Gambar 7. Hasil Baju dengan Sentuhan Draping pada Desain 2

\section{c. Desain 3}

Ukuran kain: $75 \mathrm{~cm} \times 200 \mathrm{~cm}$

Tunnel: dibuat tidak seimbang pada bagian panjang.

Peletakkan pola: tidak simetris

Pola tambahan: 1 pola lingkaran 


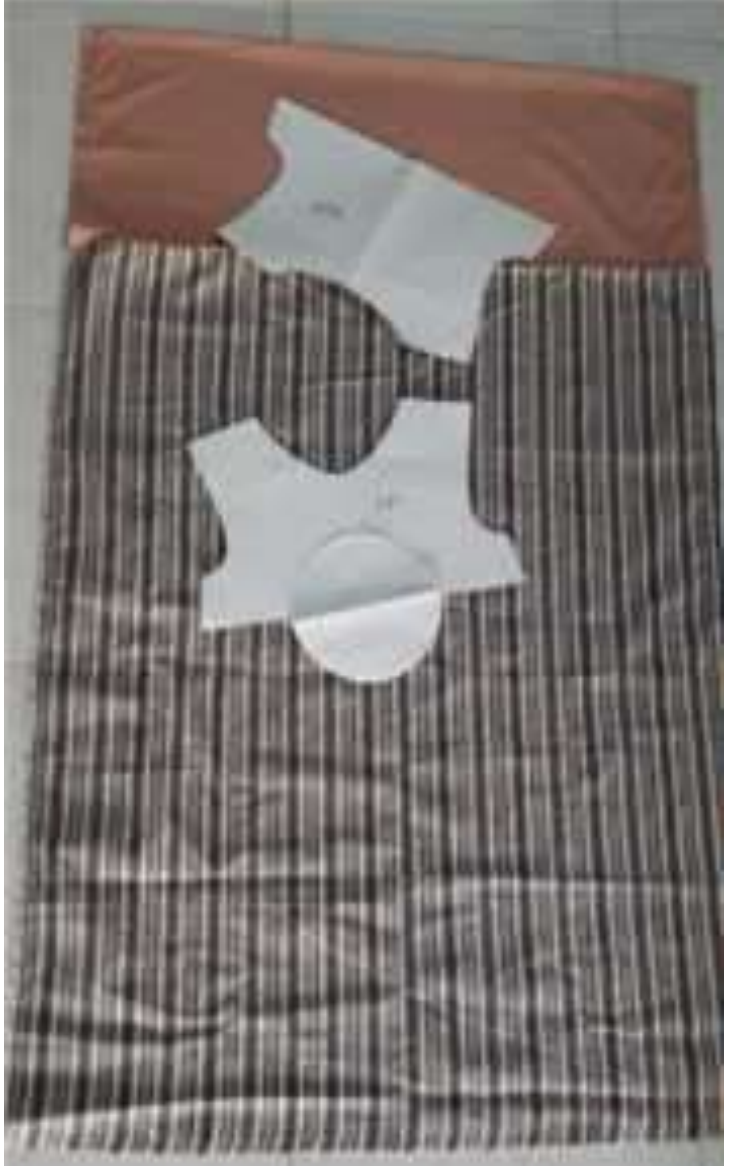

Gambar 8. Peletakkan pola

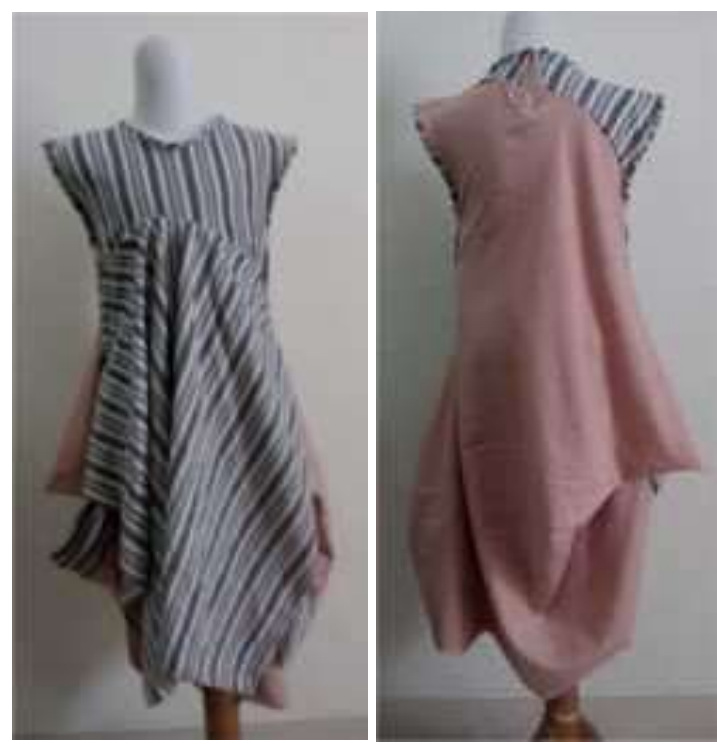

Gambar 9. Hasil busana

\section{Pembahasan Desain 3:}

Kain dengan panjang $200 \mathrm{~cm}$ dilipat dengan posisi panjang yang tidak sama, yaitu pada bagian depan memiliki panjnag lebih 50 cm dari pada kain di posisi belakang. Pola diletakkan pada posisi tidak simetris, dan di tambah 1 pola lingkaran pada bagian depan. Pola belakang berada dekat dengan lipatan. Kerung lengan depan dan belakang masingmasing di sambungkan dengan bentuk yang tidak simetris pada sisi kanan dan sisi kiri.

Hasil busana anak yang di peroleh adalah busana dengan volume pada bagian depan, belakang bawah, sisi kanan dan sisi kiri. 1 Pola lingkaran dijahit menjadi $1 / 2$ lingkaran, dan di potong sisa jahitannya sepanjang jahitan setengah lingkaran. Penggunaan 1 pola lingkaran memberikan volume pada bagian depan

\section{Efisiensi Penggunaan Kain}

Penggunaan kain pada penerapan teknik Substraction cutting, dapat dikatakan efisien. Sisa kain dihasilkan dari proses cutting adalah pada bagian kerung leher dan kerung lengan badan depan dan belakang.
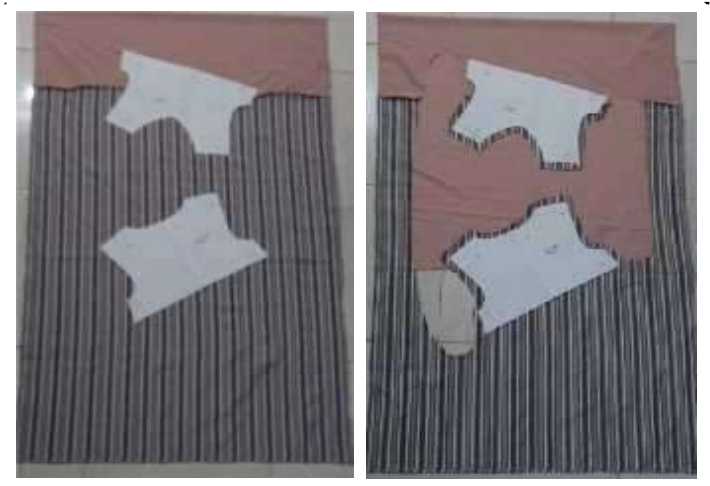

Gambar 10. Sebelum Proses Cutting dan Perubahan Kain Setelah Proses Cutting

Sisa kain dapat dimanfaat untuk keperluan finishing pada penyelesaian pembuatan busana, baik itu untuk penyelesaian kerung leher maupun kerung lengan. Sisa kain setelah digunakan untuk finsihing juga dapat dimanfaatkan untuk membuat asesoris pada busana anak. Berikut ini sisa kain yang dihasilkan dari desain 1 , desain 2, desain 3 . 


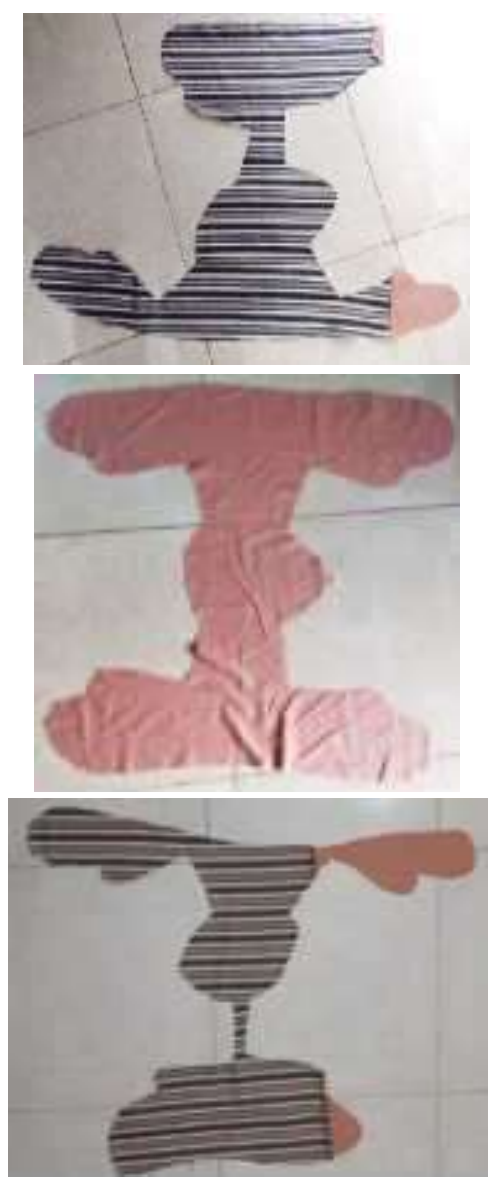

Gambar 11. Sisa Kain Desain1,2,dan 3

\section{Kecepatan Proses}

Kecepatan proses pembuatan busana dengan teknik Substraction cutting sudah nampak pada pembuatan pola. Pada proses pembuatan busana pada umumnya, untuk menghasilkan busana dengan desain1,2, dan 3, memerlukan tahapan pecah pola yang rumit, setelah itu di lakukan proses cutting bahan. Pada penerapan teknik Substraction cutting tahapan pecah pola tidak perlu dilakukan. Desain dilakukan pada saat mempersiapkan kombinasi kain. Hasil desain lebih ekspresif dan tidak terduga.

Untuk proses pada teknik menjahitnya, relaif lebih cepat, beberapa finishing harus dilakukan terlebih dahulu sebelum dilanjutkan pada proses cutting. Finishing kain tersebut dilakukan pada setiap sisi dan hasil sambungan. Berikut ini tabel yang menunjukkan perbedaan proses pembuatan busana anak dengan teknik pada umumnya dan teknik Substraction cutting.

\section{Tabel 1. Tahapan dalam Proses Pembuatan} Busana

\begin{tabular}{|c|c|c|}
\hline $\begin{array}{c}\text { Tahap } \\
\text { ke }\end{array}$ & $\begin{array}{c}\text { Proses pada } \\
\text { umumnya }\end{array}$ & $\begin{array}{c}\text { Proses dengan teknik } \\
\text { Substraction }\end{array}$ \\
\hline 1 & Membuat pola & Membuat pola dasar \\
\hline 2 & $\begin{array}{l}\text { Menentukan } \\
\text { desain }\end{array}$ & - \\
\hline 3 & $\begin{array}{l}\text { Pecah pola sesuai } \\
\text { dengan desain }\end{array}$ & - \\
\hline 4 & $\begin{array}{l}\text { Menjiplak pola } \\
\text { sesuai pecah pola }\end{array}$ & - \\
\hline 5 & $\begin{array}{l}\text { Menyiapkan } \\
\text { lembaran kain }\end{array}$ & $\begin{array}{l}\text { Menyiapkan kain } \\
\text { sesuai dengan } \\
\text { desain yang } \\
\text { diinginkan (dijahit } \\
\text { pada bagian sisi dan } \\
\text { finishing pada } \\
\text { sambungan) }\end{array}$ \\
\hline 6 & $\begin{array}{l}\text { Meletakkan pola } \\
\text { pada kain }\end{array}$ & $\begin{array}{l}\text { Meletakkan pola } \\
\text { pada kain }\end{array}$ \\
\hline 7 & $\begin{array}{l}\text { Memotong kain } \\
\text { sesuai dengan pola } \\
\text { yang telah dibuat } \\
\text { untuk seluruh } \\
\text { badan }\end{array}$ & $\begin{array}{l}\text { Memotong kain } \\
\text { hanya sampai } \\
\text { bagian kerung lengan } \\
\text { dan leher }\end{array}$ \\
\hline 8 & $\begin{array}{l}\text { Merader/ memberi } \\
\text { tanda seluruh } \\
\text { bagian dari } \\
\text { potongan badan }\end{array}$ & $\begin{array}{l}\text { Memberi tanda } \\
\text { hanya pada bagian } \\
\text { kerung lengan dan } \\
\text { leher }\end{array}$ \\
\hline 9 & Proses menjahit & Proses menjahit \\
\hline
\end{tabular}

\section{PENUTUP}

a. Teknik Substraction cutting memberikan desain busana yang tak terduga dalam setiap pembuatannya.

b. Dengan Teknik Substraction cutting untuk menghasilkan busana akhir yang relatif sama pajang depan dan belakang, dapat diperoleh dengan membuat lipatan awal kain dibuat tidak sama panjangnya.

c. Penggunaan dua pola lingkaran yang di satukan pada pembuatan busana anak dengan teknik Substraction cutting tidak disarankan, karena akan menyulitkan pada saat penggunaan 
busana. Dua lingkaran yang dijahitkan akan memberikan batasan yang mengurangi kelonggaran dalam mengenakan busana.

d. Penggunaan satu pola lingkaran dapat digunakan untuk memberikan volume pada busana anak.

e. Volume yang berlebih yang diakibatkan karena lipatan dan jahitan dapat di selesaikan dengan teknik draping, untuk dibuat sebagai hiasan yang menjadi bagian dari busana anak.

f. Teknik Substraction cutting membuang kain yang relatif sedikit, sehingga hampir sebagian kain di gunakan dan menghasilkan volume pada busana.

g. Teknik Substraction cutting memberikan kecepatan proses dalam pembuatannya, karena tahapan pecah pola tidak perlu dilakukan, meskipun busana anak yang dibuat memiliki volume di beberapa bagian.

\section{Daftar Pustaka}

Arikunto, Suharsimi. (2006). Prosedur Penelitian Suatu Pendekatan Praktik. Rineka Cipta.

Fitrah Hervianti, Dian. Nursari, Fardilah. (2017) Rancangan Busana Zero Wate dengan teknik Draping pattern making pada pola kimono. Jurnal ATRAT Vol 5 No 3.

Hardisurya, Irma. Pambudy, Ninuk Mardiana. Jusuf, Hemawan. (2011). Kamus Mode Indonesia. Gramedia Pustaka Utama Jakarta.

Nisa,Ghowatun. Setyowati, Erna. Musdalifah. (2015). Efektivitas Penggunaan Pola Kombinasi dalam Pembuatan Busana Pesta Siswa Tata Busana SMK Syafi'i Akrom Pekalongan. Jurnal EKNOBUGA Vol 2 No 1.

\footnotetext{
Riyanto Arifah A (2003). Teori Busana. Yayasan Pembangunan Indonesia (Yapemdo) Bandung
}

Webtografi:

Roberts, Julian. (2018). Free Cutting. www.juliand.com 